UDC 631.371: 621.31

\title{
ENHANCEMENT OF THE EFFICIENCY OF ULTRAVIOLET IRRADIATION OF LIQUIDS
}

\section{T. Knyzhka, Candidate of Technical Sciences, Senior Lecturer}

O. Romanenko, Candidate of Technical Sciences, Senior Lecturer

S. Usenko, Candidate of Technical Sciences, Assistant Professor

National University of Life and Environmental Sciences of Ukraine e-mail:knizhkatetiana@mail.ru

\begin{abstract}
The article considers the conditions for the full absorption of ultraviolet radiation to create energy-saving radiation technology. The purpose of the research is to obtain the dependence of the relative irradiance of cylindrical layers of the medium under different absorption coefficients.

The paper analyzes the technological schemes of radiation, which will increase the energy efficiency of irradiation of liquid media. The conditions of irregularity of absorption of radiation had been investigated. An expression that takes into account the optical properties of the medium and the geometry of the beam is obtained and allows us to determine the general principles of the layout of the technological scheme of volume irradiation.
\end{abstract} irradiation

Keywords: ultraviolet irradiation, energy saving, energy efficiency of

Introduction. To create an energy saving technology for irradiation of liquid media by an ultraviolet stream, it is necessary to embody it in a condition in which the radiation energy is completely absorbed by the volume of the irradiated medium. It is advisable to carry out an analysis of the irradiator, based on observance of the principle of ensuring uniformity of irradiation.

Analysis of recent researches and publications. The irregularity of absorption of radiation in case of volumetric irradiation is due to the exponential dependence of the intensity of radiation penetrating into the volume on the depth of penetration. [1, 2]. In order to increase the uniformity of volumetric absorption, regulate the thickness of the irradiated layer or the section of the channel where the irradiated liquid moves; perform 
the selection of geometry of the system of emitters of a submerged type; using different mixing devices $[3,4]$.

Purpose - to investigate the dependence of relative irradiance of cylindrical layers of the medium at various absorption coefficients for an irradiator.

Methods. The paper uses methods of optical analysis within the limits of quantum-mechanical theory.

Results. The measures described in [2] allow in practice to provide high quality and uniformity of volume radiation of the medium, however, the ability to compensate for the attenuation of radiation in the medium is to increase its spatial density by reforming the beam geometry. We will show such an opportunity by analyzing the Helmholtz wave equation in which the refraction index is adopted as a complex

$$
\frac{\partial^{2} u}{\partial x^{2}}+\frac{\partial^{2} u}{\partial y^{2}}+\frac{\partial^{2} u}{\partial z^{2}}+\omega \cdot\left(n_{0}+i \cdot n_{1}\right)^{2} \cdot u=0,
$$

where $u(x, y, z, t)-\mathrm{a}$ function that describes the amplitude and phase of the radiation wave; $\omega$ - frequency of oscillations; $n$ - refractive index.

The imaginary part of the refractive index determines the attenuation of radiation in the medium. The substitution of the solution of this equation in the form $u=U \cdot e^{-i \cdot \cdot \cdot \xi}$ allows us to obtain, using the method of asymptotic approximations, the usual differential equation

$$
2 \cdot n_{0}^{2} \cdot \frac{d U}{d \xi}+n_{0} \cdot \frac{U}{\Gamma} \cdot \frac{d}{d \xi}\left(\frac{\Gamma}{n_{0}}\right)=-2 \cdot n_{1} \cdot \omega \cdot n_{0}
$$

where $\xi$ - an indicator defining the direction of the wave front; $d / d \xi$-derivative along the beam of radiation; $\Gamma$ - geometrical divergence of the radiation beam.

The general solution of this equation has the form

$$
U=A \cdot \sqrt{\frac{1}{\Gamma \cdot n_{0}}} \cdot e^{-v \int_{M_{0}}^{M} n_{1}(\xi) \frac{d \xi}{n_{0}}},
$$

where $A$ - constant value; $M_{0}, M$ - points on the beam axis.

Given that the intensity of the wave $I \equiv U^{2}, d \xi / n_{0}=d l$ (where $d l$ - element of the path length of the beam), $a=2 \omega n_{1}$ 


$$
I=\left(\Gamma \cdot n_{0}\right)^{-1} \cdot e^{-\int_{M_{0}}^{M} a(l) d l},
$$

The resulting expression takes into account the optical properties of the medium and the beam geometry (the solution of this functional equation relative to $l$ for the constant $a$ and a given function $\Gamma(l)$ satisfying the restrictions on the deviation $I$ ). The expression allows us to determine the general principles of the layout of the technological scheme of volume irradiation: the spatial flow density on its path in the material must be formed in such a way as to compensate for its attenuation through absorption.

We will analyze the basic properties of technological schemes.

The ring volumetric irradiator directs the radiation flowing to the center to the volume of the irradiated liquid flowing in the quartz tube.. External radius of fluid flow $-r$; flux of radiation $-\Phi_{0}$.

To estimate the change in irradiation within the volume of the treated medium, we will take into account the values of the surface of elementary cylinders of the medium with radius $r_{x}\left(r_{x}<r\right)$ and height $b$. Radiation of the outer surface of the cylinder of fluid $E_{0}=\Phi_{0} / 2 \pi r b$.

The radiation flux falling on the surface of an elementary cylinder with radius $r_{x}$ decreases in comparison with $\Phi_{0}$ due to absorption in the layer of liquid in the thickness $r-r_{x}$ and will make

$$
\Phi_{x}=\Phi_{0} \cdot e^{-a \cdot\left(r-r_{x}\right)} .
$$

Therefore, irradiation is defined as

$$
E_{x}=\frac{\Phi_{0} \cdot e^{-a \cdot\left(r-r_{x}\right)}}{2 \cdot \pi \cdot r_{x} \cdot b} .
$$

Taking the correlation of two boundary irradiances and introducing the designation $k=r / r_{x}$ we obtain

$$
\frac{E_{x}}{E_{0}}=k \cdot e^{-a \cdot r\left(1-\frac{1}{k}\right)}
$$


Let's analyze the dependence of the irradiance ratio $E_{x} / E_{0}$ on the ratio $r / r_{x}$ to determine the most effective depth (radius of the tube) of uniform irradiation of the solution.

The dependences $E_{x} / E_{0}=f\left(r_{x}\right)$ are calculated for seven values of $a(0 ; 1 / 2 r ; 1 / r$; $1 / 0,75 r ; 1 / 0,5 r ; 1 / 0,25 r ; 1 / 0,1 r)$. It was established that at a depth from $r$ to $0,3 r$ the irradiance varies relatively little in the range of $0,7 \cdot E_{0} \ldots 1,35 E_{0}$. This provides the basis for the appropriate selection of parameters of a volume illuminator $(r)$ depending on the properties of the medium $(a)$ to expect the uniformity of its processing in depth.

Discussion. Irradiating the liquid medium in the considered technological scheme with the absorption coefficient a, which lies in the range from $1 / 0,5 r$ to $1 / 0,75 r$, or close to it, it is possible to achieve a fairly uniform treatment of the medium by ultraviolet flow of processing in depth.

\section{References}

1. Chervinskyi, L.S., Usenko, S.M., Knyzhka, T.S., Lutsak, Ia.M. (2016). Metod vyznachennia prostorovoi fotosynteznoi oprominenosti. [The method of determining the spatial photosynthesis exposure]. Tekhnichna elektrodynamika. Inst. Elektrodynamiky NAN Ukrainy, 5, 88-90.

2. Chervinskyi, L.S., Romanenko, O.I., Knyzhka, T.S., Lutsak, Ia.M. (2017). Pidvyschennia efektyvnosti optychnoho oprominiuvannia $v$ biotekhnichnykh systemakh kultyvatsiinykh sporud roslynnytstva. [Increasing the efficiency of optical radiation in biotechnical systems of plant cultivating plants]. Enerhetyka i avtomatyka, 2, 78-88.

3. Chervinskyi, L.S., Knyzhka, T.S. (2016). Teoretychne obhruntuvannia mekhanizmu keruvannia vplyvom optychnoho vyprominiuvannia na biolohichni systemy na osnovi fotoreaktyvatsii [Theoretical substantiation of the mechanism of control of the influence of optical radiation on biological systems on the basis of photoreactivation]. Tekhnika ta enerhetyka APK. Naukovyi visnyk Natsionalnoho universytetu bioresursiv i pryrodokorystuvannia Ukrainy, 242, 106-115.

4. Chervinskyi, L.S., Romanenko, O.I. (2016). Vymohy do spektralnoho skladu shtuchnykh dzherel optychnoho vyprominiuvannia dlia vyroshchuvannia roslyn $\mathrm{v}$ sporudakh zakrytoho hruntu [Requirements for the spectral composition of artificial sources of optical radiation to grow plants in the greenhouses]. Enerhetyka i avtomatyka, 3 (29), 88-95. 


\title{
ПІДВИЩЕННЯ ЕФЕКТИВНОСТІ УЛЬТРАФІОЛЕТОВОГО ОПРОМІНЕННЯ РІДИН
}

\section{Т. С. Книжка, О. І. Романенко, С. М. Усенко}

Анотація. $У$ статті розглянуто умови для повного поглинання ультрафіолетового випромінювання для створення енергозберігаючої технології опромінення. Метою проведених досліджень є отримання залежності відносної опроміненості ииліндричних шарів середовища при різних коефіцієнтах поглинання.

У роботі проведено аналіз технологічних схем опромінення, щзо дозволить підвищити енергетичну ефективність опромінення рідких середовищ. Досліджено умови нерівномірності поглинання випромінювання. Отримано вираз, який враховує оптичні властивості середовища й геометрію пучка та дозволяє визначити загальні принципи компонування технологічної схеми об'ємного опромінення.

Ключові слова: ультрафіолетове опромінення, енергозбереження, енергетична ефективність опромінення

\section{ФОТОМЕТРИЧЕСКИЕ ОСНОВЫ СОВЕРШЕНСТВОВАНИЯ КОЛЬЦЕВОГО ОБЛУЧАТЕЛЯ \\ Т. С. Книжка, О. И. Романенко, С. Н. Усенко}

\begin{abstract}
Аннотация. В статье рассмотрены условия для полного поглощения ультрафиолетового излучения для создания энергосберегающей технологии облучения. Целью проведенных исследований является получение зависимости относительной облученности иилиндрических слоев среды при различных коэффициентах поглощения.

В работе проведен анализ технологических схем облучения, что позволит повысить энергетическую эффективность облучения жидких сред. Исследовань условия неравномерности поглощения. Получено выражение, учитывающиии оптические свойства среды и геометрию пучка, и позволяет определить общие принципы компоновки технологической схемы объемного облучения.
\end{abstract}

Ключевые слова: ультрафиолетовое облучение, энергосбережение, энергетическая эффективность облучения. 